\title{
Evaluation of tree measurements after the reconstruction of tree-row system in five narrow streets of Debrecen
}

\author{
${ }^{1}$ Anikó André Zsiláné - ${ }^{2}$ László Zsila - ${ }^{1}$ Imre Holb \\ ${ }^{1}$ University of Debrecen, Faculty of Agricultural and Food Sciences and Environmental Management, \\ , Institute of Horticulture, Debrecen, Hungary \\ ${ }^{2}$ Zsila László Private Enterprise, Debrecen, Hungary \\ zsilane.andre.aniko@gmail.com
}

\begin{abstract}
SUMMARY
Viable urban environment is largely dependent on the size, condition and distribution of urban green spaces within and around cities. Treerows in streets are one of the most essential elements of urban green spaces. The aim of this study was to evaluate tree taxa compositions and lifespan values of trees in tree-row system with special reference to five narrow streets (Garai, Jókai, Tanító, Csokonai and Zsák) of Debrecen. Tree numbers, tree taxa and the origin of tree taxa were determined in two years (2009 and 2017). As a next step, six selected taxa (Pyrus calleryana 'Chanticleer', Acer tataricum, Sorbus intermedia 'Browseri', Magnolia kobus, Acer platanoides 'Olmsted', and Crataegus x lavalleei 'Carrierei') were further estimated for the following lifespan parameters: i) trunk diameter (cm), ii) tree crown size (m), iii) trunk status (in 0-5 grades), iv) tree crown status (in 0-5 grades), v) estimated tree viability (in 0-5 grades), and vi) tree value in Ft. Our results showed that the numbers of tree taxa were 9 and 11 in 2009 and 2017 as well as an overall 279 and 282 trees were evaluated in 2009 and in 2017, respectively. More than 60\% of the trees were native or similar to native taxa. The largest and the lowest trunk diameters were achieved for Pyrus calleryana 'Chanticleer' and for Acer tataricum, respectively. The largest and the lowest tree crown diameters were achieved for Acer platanoides 'Olmsted' and for Magnolia kobus, respectively. The best and the worst trunk statuses by 2017 were achieved for Pyrus calleryana 'Chanticleer' and for Crataegus x lavalleei, respectively. The best and the worst tree crown statuses by 2017 were achieved for Pyrus calleryana 'Chanticleer' and for Acer tataricum, respectively. The best estimated tree viability status was achieved for Pyrus calleryana 'Chanticleer' and for Acer platanoides. Overall tree values were 2.73 times higher in 2017 compared to 2009. In conclusion, this study clearly demonstrated the importance of appropriate choice of tree taxa for an establishment of tree-row system in narrow street conditions.
\end{abstract}

Keywords: tree-row system, tree measurements, green urban space

\section{INTRODUCTION}

In general, urbanization is the increasing numbers of cities and citizens coupled with the spreading of city culture and lifestyle. More than half of the world human population lives in cities. This will increase in the future especially in those countries where large cities and metropolises grow dynamically. Viable urban environment is largely dependent on the size, condition and distribution of urban green spaces within and around the cities. One of the most essential elements of urban green spaces are the tree-rows in streets. In this system, trees usually planted along roads, railways, rivers and paths in rows. They have the most frequent connections with the citizens. On the other hand, tree-row systems are in the worst ecological conditions as well as the most difficult to repair compared to other urban green spaces (Schmidt 2003).

Tree species have to have special biological and ecological features if they are decided to plant in cities. The trees have to i) grow fast, ii) have long life ability, iii) have linear trunk, iv) have strong root system, v) have aesthetic value, vi) have cheap tree maintenance and vii) adopt the city various ecological conditions (e.g. air pollution, road salting, small living space). There are advantages of tree species with small leaves and early leaf growth (Schmidt 1988).

There are several professional books which describe tree species suitable under city circumstances in Hungary (Nagy 1980, Schmidt 2003, Schmidt and Varga 2004, Schmidt and Tóth 2006, Szabó 2015).
Available tree taxa for city circumstances increased to double from the 1990's until 2004 in the market (Schmidt and Tóth 2006). Lists of tree rows in public domain are published yearly by the Hungarian Ornamental Gardener Association (Szaller 2013, 2017; Szabó 2015).

In Debrecen, trees live in disadvantageous ecological environment in the city centre. Their living spaces are narrow due to urban built environment both above and under the soil surface. Above the surface, the walls of the buildings and several civil engineering infrastructures limit growth of the tree trunk and crown. Under the surface, public utility system in the soil reduces root growth and road salting and chemical emission decrease viability of the tree root system. In addition, water and air supplies in these soils are inconsistent due to pavements of roads. These negative effects are stronger on trees planted in narrow streets.

The aim of this study was to evaluate tree taxa compositions and lifespan values of trees in tree-row system with special reference to five narrow streets of Debrecen.

\section{MATERIALS AND METHODS}

The study was performed in the centre of Debrecen, Eastern-Hungary, selecting five typical narrow streets with single-storey houses. The selected streets were Garai, Jókai, Tanító, Csokonai and Zsák (Figure 1). 
Figure 1: Physical map for trees on the selected streets (Garai, Jókai, Tanító, Csokonai and Zsák) for evaluating tree-row system in narrow streets of Debrecen

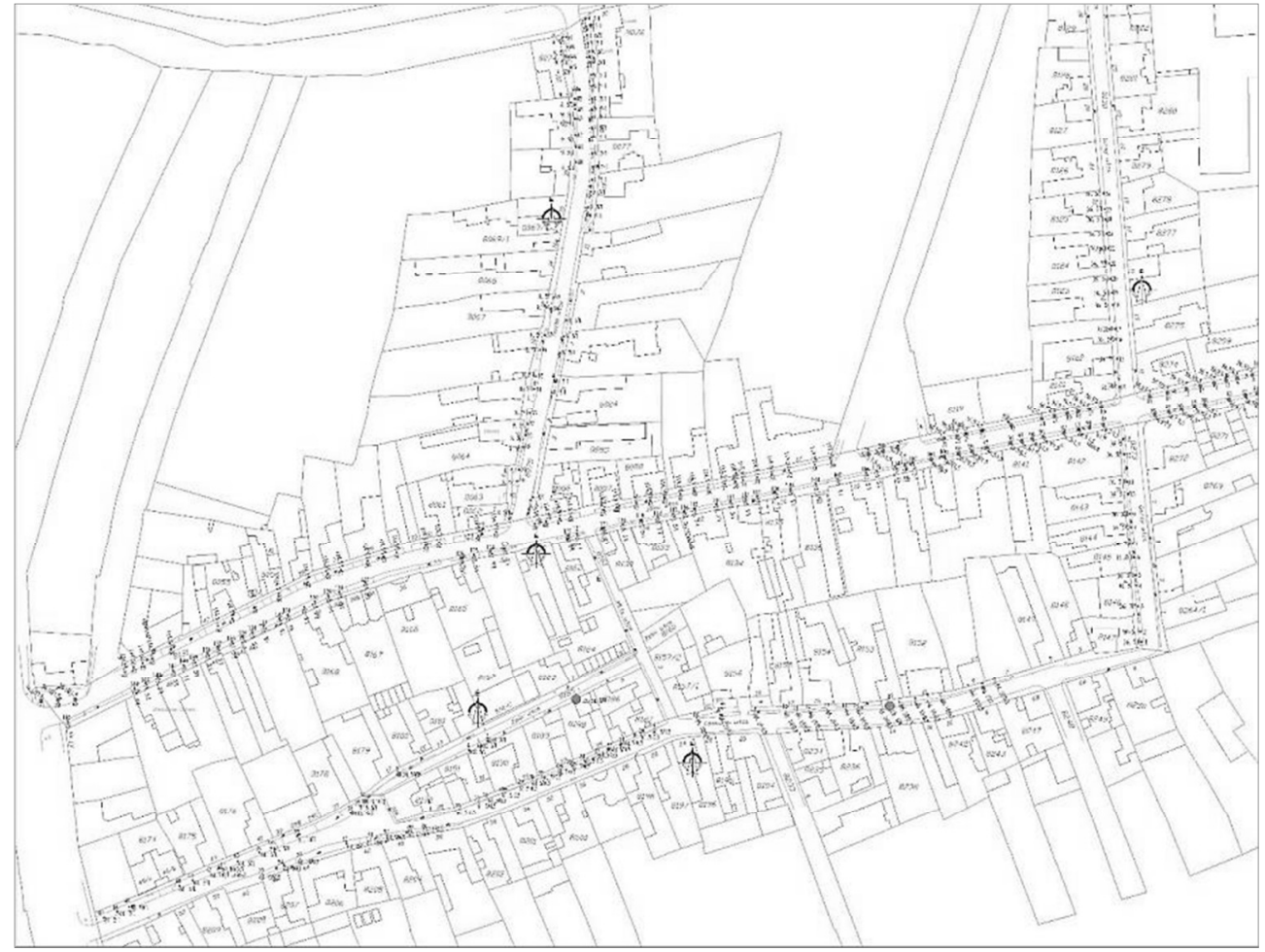

In these streets, tree-row system was established in the 1930's with the direction of Ferenc Pohl. The tree species was Celtis occidentalis. These trees become old and weakened by the new century therefore trees replaced with new young trees. In 2009 and 2017, this newly established tree-row system was evaluated by the modified methods of Radó (1981, 1999). Observations were made in all selected streets and on all trees in both years.

First tree numbers and tree taxa were identified. Then the origin of tree taxa was established as native, alien or similar to native taxa. Similar to native taxa means those tree taxa which live similar ecological conditions like native tree taxa. Then six selected taxa (Pyrus calleryana 'Chanticleer', Acer tataricum, Sorbus intermedia 'Browseri', Magnolia kobus, Acer platanoides 'Olmsted', and Crataegus $\mathrm{x}$ lavalleei 'Carrierei') were further estimated for the following lifespan parameters: i) trunk diameter $(\mathrm{cm})$, ii) tree crown size (m), iii) trunk status (in 0-5 grades), iv) tree crown status (in 0-5 grades), v) estimated tree viability (in $0-5$ grades), and vi) tree value in $\mathrm{Ft}$. Trunk diameter was measured $1 \mathrm{~m}$ above the surface. Trunk status represents the health and vitality of the trunk in a five grade scale. Tree value was calculated based on tree age, trunk diameter, and the grades of trunk and tree crown status. In case of parameter iiivi) a 5 scale grading system was used in which grade 1 represented weak, grade 2 middle-weak, grade 3 middle, grade 4 good, grade 5 excellent features of the observed parameter.

\section{RESULTS}

In the five evaluated narrow streets, the numbers of tree taxa were 9 and 11 in 2009 and 2017, respectively (Table 1). Numbers of trees within the taxa varied from 3 to 68 and from 3 to 52 in 2009 and 2017 , respectively. Total numbers of trees was similar in both years (279 in 2009 and 282 in 2017).

Numbers of some tree taxa changed during the 8 years due to some reasons. In case of Malus prattii 'Professor Sprenger', trees were not able to adopt the environment and they had to replace with new taxa. These taxa are not suitable to plant in the centre of Debrecen in narrow streets. In case of Pyrus calleryana 'Chanticleer', tree numbers were increased by 2017 as trees are well suited the ecological conditions of Garai street. Numbers of Acer tataricum did not changed, showing a good ecological adaptability of the taxa. Several trees of Sorbus and Magnolia kobus taxa died in Csokonai and Jókai streets, respectively, indicating that these taxa are not really suitable in narrow streets. Overall the numbers of Acer platanoides also increased.

In $2009,30 \%$ of the trees were native and $35 \%$ was similar to native taxa while the alien taxa were $35 \%$. In 2017 , the native taxa increased to $40 \%$ while $37 \%$ and $23 \%$ of the trees belonged to alien and similar to native taxa, respectively (Figure 2). 
Tree taxa and mean values of tree value in $\mathrm{Ft}$ and number of trees in 2009 and 2017 for the 5 evaluated streets (Garai, Jókai, Tanító, Csokonai and Zsák) in Debrecen

\begin{tabular}{|c|c|c|c|c|}
\hline Tree taxa & $\begin{array}{c}\text { Tree value in Ft } \\
2009\end{array}$ & $\begin{array}{c}\text { Tree number } \\
2009 \\
\end{array}$ & $\begin{array}{l}\text { Tree value in Ft } \\
2017\end{array}$ & $\begin{array}{c}\text { Tree number } \\
2017 \\
\end{array}$ \\
\hline 1. Pyrus calleryana 'Chanticleer' & 416000 & 26 & 1545600 & 30 \\
\hline 2. Acer tataricum & 34000 & 17 & 1022200 & 17 \\
\hline 3. Sorbus intermedia 'Browseri' & 572000 & 34 & 1375400 & 31 \\
\hline 4. Magnolia kobus & 1113000 & 59 & 2531200 & 51 \\
\hline 5. Acer platanoides 'Olmsted' & 1232000 & 68 & 2573200 & 52 \\
\hline 6. Acer platanoides & - & - & 932400 & 21 \\
\hline 7. Acer platanoides 'Columnare' & - & - & 484800 & 22 \\
\hline 8. Crataegus x lavalleei 'Carrierei' & 300000 & 20 & 1756800 & 35 \\
\hline 9. Malus prattii 'Professor Sprenger' & 817000 & 43 & - & - \\
\hline 10. Thuja occidentalis 'Smaragd' & - & - & 204000 & 4 \\
\hline 11. Juniperus virginiana & 76800 & 3 & 173400 & 3 \\
\hline 12. Prunus serrulata & 81600 & 3 & 153000 & 3 \\
\hline mixed direct planting & 91160 & 5 & 170200 & 3 \\
\hline mixed weed tree & 17000 & 1 & 50720 & 10 \\
\hline Overall & 4750560 & 279 & 12972920 & 282 \\
\hline
\end{tabular}

Figure 2: Origin of tree taxa (alien, native, similar to native-hybrid) in the 5 evaluated streets (Garai, Jókai, Tanító, Csokonai and Zsák) in Debrecen in 2009 and in 2017
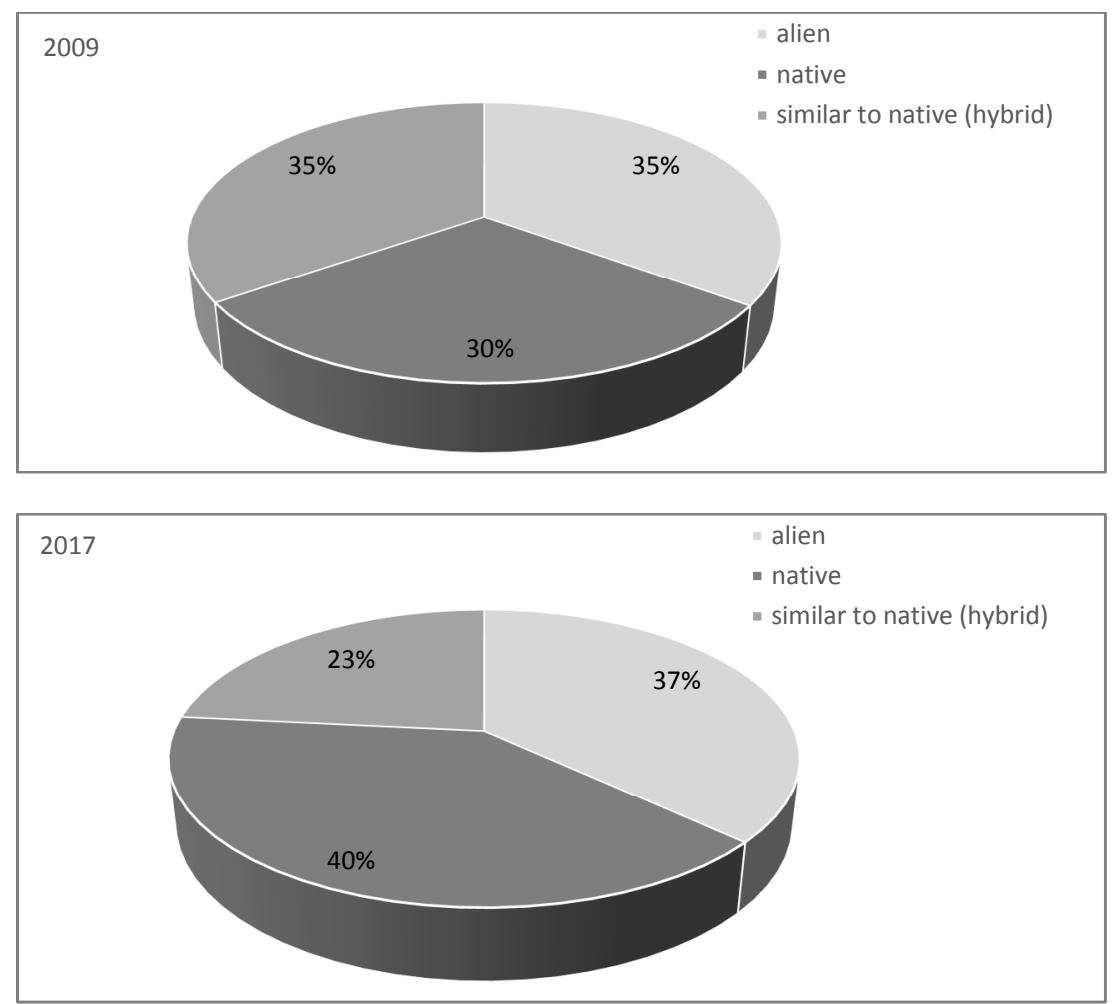

Trunk diameter of the six tree taxa ranged between 4.9 and $9.8 \mathrm{~cm}$ and between 8.9 and $16.6 \mathrm{~cm}$ in 2009 and 2017, respectively (Figure 3). The largest and the lowest trunk diameters were achieved for Pyrus calleryana 'Chanticleer' and for Acer tataricum, respectively. The taxa of Acer tataricum, Magnolia kobus and Crataegus $x$ lavalleei had significantly lower trunk growth during the 8 years compared to Pyrus, Sorbus or Acer platanoides species.
Tree crown diameter of the six tree taxa ranged between 0.66 and $1.5 \mathrm{~m}$ and between 2.4 and $3.7 \mathrm{~m}$ in 2009 and 2017, respectively (Figure 4). The largest and the lowest tree crown diameters were achieved for Acer platanoides 'Olmsted' and for Magnolia kobus, respectively. Most taxa produced twice to three times larger tree crown in 2017 compared to that of in 2009 with the exceptions of Magnolia kobus and Crataegus $x$ lavalleei. 
Trunk status of the six tree taxa ranged between 4.95 and 5.0 and between 3.7 and $4.9 \mathrm{~cm}$ in 2009 and 2017, respectively (Figure 5). The best and the worst trunk statuses by 2017 were achieved for Pyrus calleryana 'Chanticleer' and for Crataegus x lavalleei, respectively. All other taxa showed a significantly worse trunk status during the 8 years compared to Pyrus calleryana 'Chanticleer' species.

Figure 3: Trunk diameter of six selected tree taxa in five narrow streets (Garai, Jókai, Tanító, Csokonai and Zsák) in Debrecen in 2009 and 2017

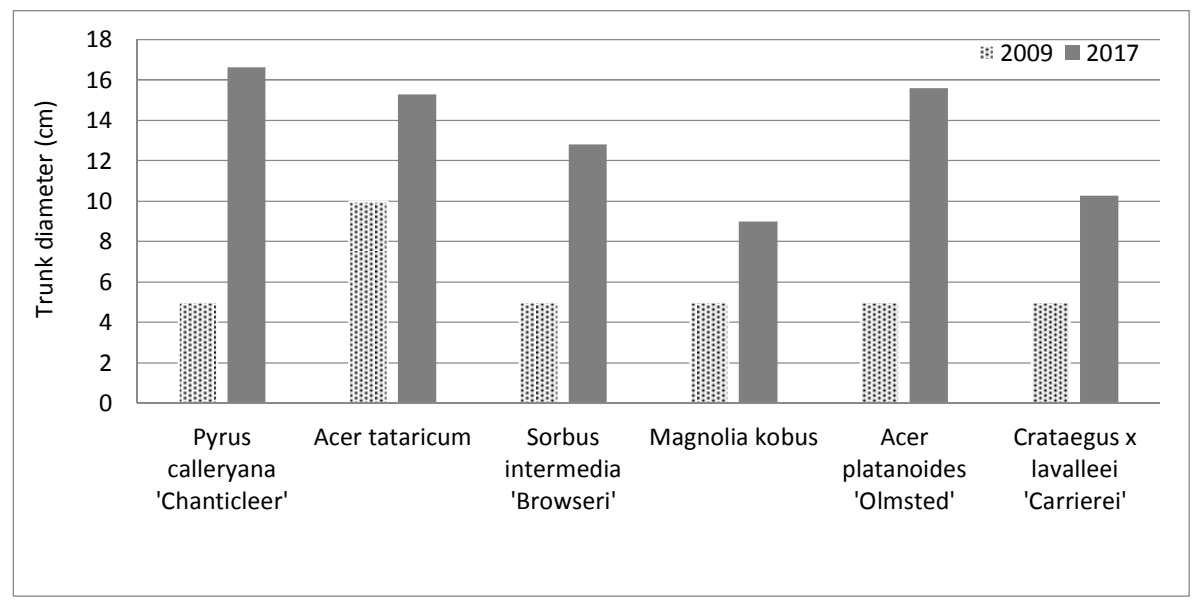

Figure 4: Tree crown diameter of six selected tree taxa in five narrow streets (Garai, Jókai, Tanító, Csokonai and Zsák) in Debrecen in 2009 and 2017

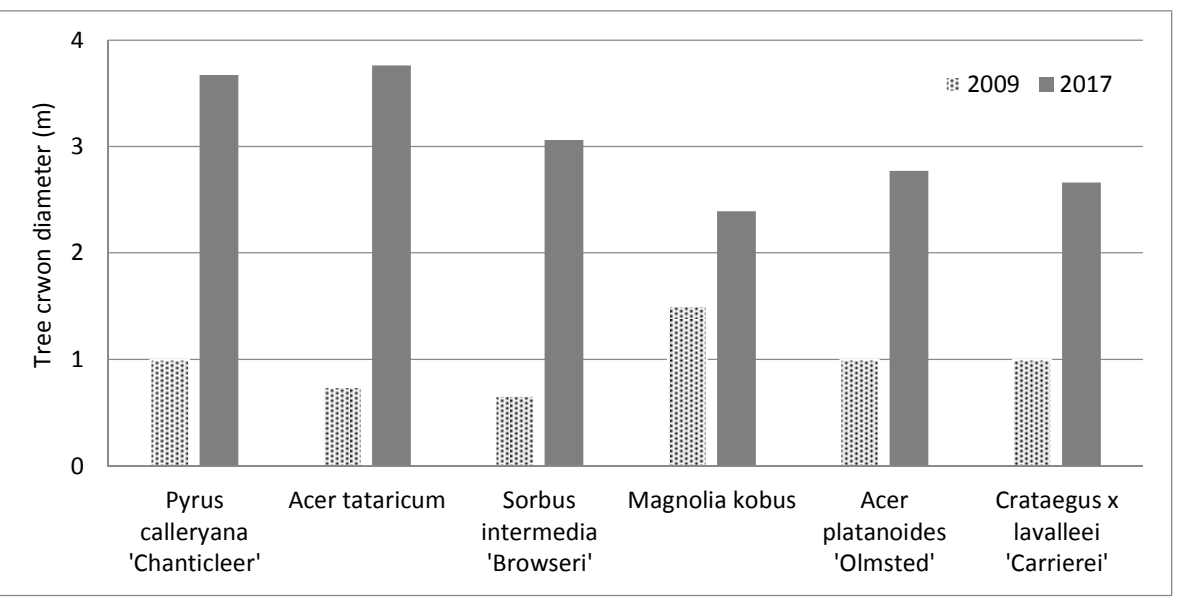

Figure 5: Trunk status of six selected tree taxa in five narrow streets (Garai, Jókai, Tanító, Csokonai and Zsák) in Debrecen in 2009 and 2017

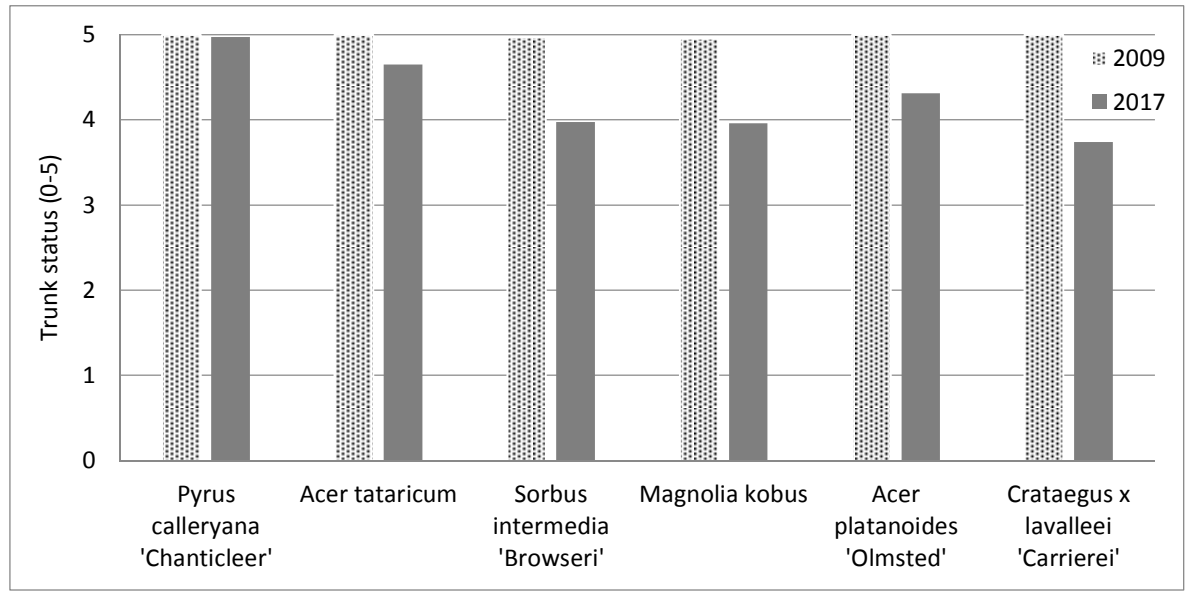


Tree crown status of the six tree taxa ranged between 4.9 and 5.0 and between 3.4 and $4.7 \mathrm{~m}$ in 2009 and 2017, respectively (Figure 6). The best and the worst tree crown statuses by 2017 were achieved for Pyrus calleryana 'Chanticleer' and for Acer tataricum, respectively.
Estimated tree viability of the six tree taxa ranged between 2.0 and 3.0 and between 3.7 and $4.8 \mathrm{~m}$ in 2009 and 2017, respectively (Figure 7). The best estimated tree viability status was achieved for Pyrus calleryana 'Chanticleer' and for Acer platanoides.

Figure 6: Tree crown status of six selected tree taxa in five narrow streets (Garai, Jókai, Tanító, Csokonai and Zsák) in Debrecen in 2009 and 2017

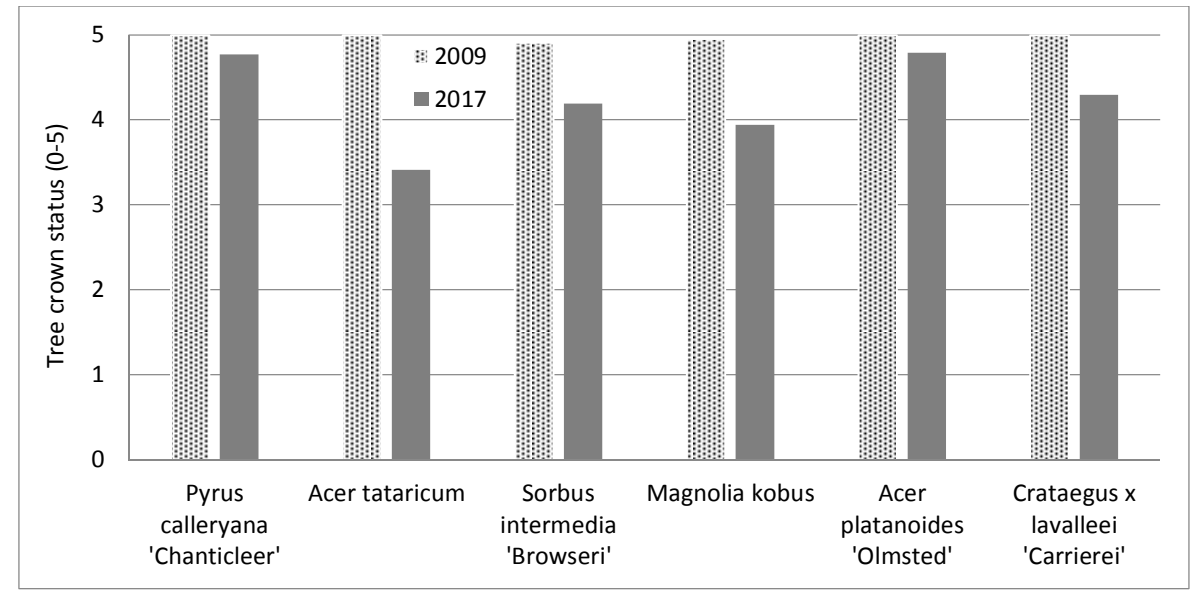

Figure 7: Estimated tree viability of six selected tree taxa in five narrow streets (Garai, Jókai, Tanító, Csokonai and Zsák) in Debrecen in 2009 and 2017

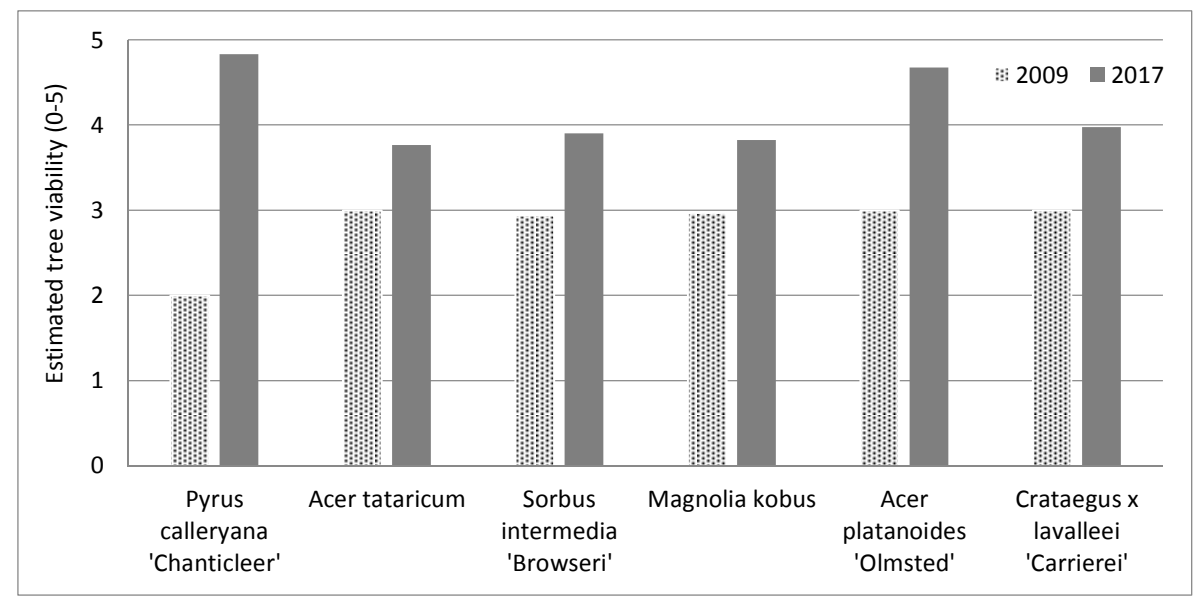

Tree values are greatly increased for each taxon from 2009 until 2017 (Table 1). Overall tree values were 2.73 times higher in 2017 compared to 2009 (4 $750560 \mathrm{Ft}$ and $12972920 \mathrm{Ft}$, respectively).

\section{CONCLUSION}

This study evaluated tree species compositions and tree lifespan in a tree-row system for narrow streets of
Debrecen. The study showed that Pyrus calleryana 'Chanticleer' and Acer platanoides were the most successful taxa among the evaluated six taxa for a tree-row system under urbanized conditions. This study clearly demonstrated the importance of appropriate choice of tree taxa for an establishment of tree-row system in narrow street conditions. Our study emphasizes the role of tree-rows as green surfaces in complex environmental improvement.

\section{REFERENCES}

Nagy B. (1980): Díszfák, díszcserjék termesztése és felhasználása. Mezőgazdasági Kiadó. Budapest. 455.

Radó D. (1981): Fák a betonrengetegben. Mezőgazdasági Kiadó. Budapest. 100 .
Radó D. (1999): Bel- és külterületi fasorok EUmódszer szerinti értékelése. Lélegzet. 1999/7-8: melléklet. Budapest.

Schmidt G. (1988): A kert élő díszei - A növényalkalmazás tudománya. Mezőgazdasági Kiadó. Budapest. 250. 
Schmidt G. (2003): Növények a kertépítészetben. Mezőgazda Kiadó. Budapest. 525.

Schmidt G.-Tóth I. (2006): Kertészeti dendrológia. Mezőgazda Kiadó. Budapest. 403.

Schmidt G.-Varga G. (2004): Famutató. Sopron. 210

Szabó K. (2015): Közterületi sorfák jegyzéke 2015. Magyar Díszkertészek Szövetsége.
Szaller V. (2013): Útmutató a fák nyilvántartásához és egyedi értékük kiszámításához. Magyar Faápolók Egyesülete. http://www.faapolok.hu/nincs-kategorizalva/egyesuletunk-ujkiadvanya-utmutato-a-fak-nyilvantartasahoz-es-egyedi-ertekukkiszamitasahoz/

Szaller V. (2017): Útmutató a vizuális és müszeres favizsgálatok elvégzéséhez és dokumentálásához. Magyar Faápolók Egyesülete. https://drive.google.com/file/d/1SNB3UcJgZ0t2X Zn0SIJGbs4neIwV2_ld/view 